\title{
NUMERICAL SIMULATION OF TEMPERATURE DISTRIBUTION IN THE GAS TURBINE BLADE
}

\author{
Dariusz Jakubek \\ Faculty of Mechanical Engineering, Cracow University of Technology, Cracow, Poland \\ *E-mail of corresponding author: darek.jakubek01@gmail.com
}

\section{Resume}

This paper concentrates on temperature distribution in the gas turbine blade equipped by the cooling holes system on transient heat transfer. The present study requires the specification of internal and external boundary conditions. The calculations had been done using both Crank-Nicolson algorithm, explicit and implicit methods, in which different heat transfer coefficients on internal cooling surfaces of the holes were applied. The value of coefficients has a direct and crucial impact on the final result. The heat transfer coefficient of cooling the working surface of the of heat pipes was $1600 \mathrm{~W} /(\mathrm{m} 2 \mathrm{~K})$. It was found that there were no significant differences of temperature distribution in comparison of results from explicit method in the Ansys analysis, Crank-Nicolson algorithm and implicit method in Matlab. The simulation is based on Finite Element Method, which uses the Crank Nicolson algorithm.

Available online: https://doi.org/10.26552/com.C.2021.3.B227-B236

\section{Article info}

Received 27 September 2020

Accepted 7 December 2020

Online 24 May 2021

\section{Keywords:}

film cooling, heat transfer, gas turbine blade, numerical method

ISSN 1335-4205 (print version) ISSN 2585-7878 (online version)

\section{Introduction}

Development of materials and technology, used in the construction of turbine blades and cooling systems, contributed to an increase of combustion temperature of the fuel. Therefore, the first (and often the second) turbine stage is cooled by the air extracted from the compressor. The high compression ratios cause a significant increase in the temperature of the compressed air, which is approximately $1200{ }^{\circ} \mathrm{F}(649$ $\left.{ }^{\circ} \mathrm{C}\right)$. That causes the thermal stresses on cooperating elements - mainly gas turbine blades. To minimize the risk of premature material wear, solutions are used to reduce the temperature of the vanes in the form of cooling channels. The following section shows the main types of direct cooling:

1. Convection cooling,

2. Impingement cooling,

3. Film cooling,

4. Full-coverage film cooling,

5. Transpiration cooling.

An increase of the working medium temperature by $100{ }^{\circ} \mathrm{F}\left(56{ }^{\circ} \mathrm{C}\right)$ contributes to the increase of the power output by $8-13 \%$ and the increase of the overall efficiency $2-4 \%$ for a single system. The internal singleflow cooling used in the 1960's allowed the flue gas temperature to reach $\sim 850{ }^{\circ} \mathrm{C}$. Further development in the form of membrane cooling, combined with one-cycle air flow (1970's), increased the temperature resistance to over $1000{ }^{\circ} \mathrm{C}$. This type of cooling works on the principle of radial air flow through the profiled channels of turbine blades and vanes. The radial flow through the channels provides multiple meandering air movement that removes the heat from the walls. This is currently the most widespread idea of cooling. The middle section is cooled by the forced convection, the air flows around the ribs that give off heat. The leading edge is also cooled by exhaust nozzles. The circulating air leaves the inner surface through the outlets at the trailing edge. Jet cooling is a part of the above solution. This is a type of high-efficiency convection cooling. The cooling air is directed, at a high speed, to the inner part - the front part of the blade. The high speed of the medium causes an increase in the heat transfer coefficient and thus a greater amount of heat is taken from the material [1-3].

Han et al. [4] performed an experimental investigation to study the effects of the hole pitch and the blowing ratio on the leading edge region film cooling performance of a twist turbine blade with three rows of film holes under rotating conditions.

Mishra and Sanjay [5] studied the radiative heat transfer of turbine blade cooling model and provided the unique performance maps for power utility designers.

Kamal-Omar et al. [6] undertook studies about the performance of a gas turbine, which depends on the air temperature and proved that the cooling systems are necessary to reduce the heat rate, as well as to increase the turbine's power output.

The major goal of Kim et al. [7] was to redesign 


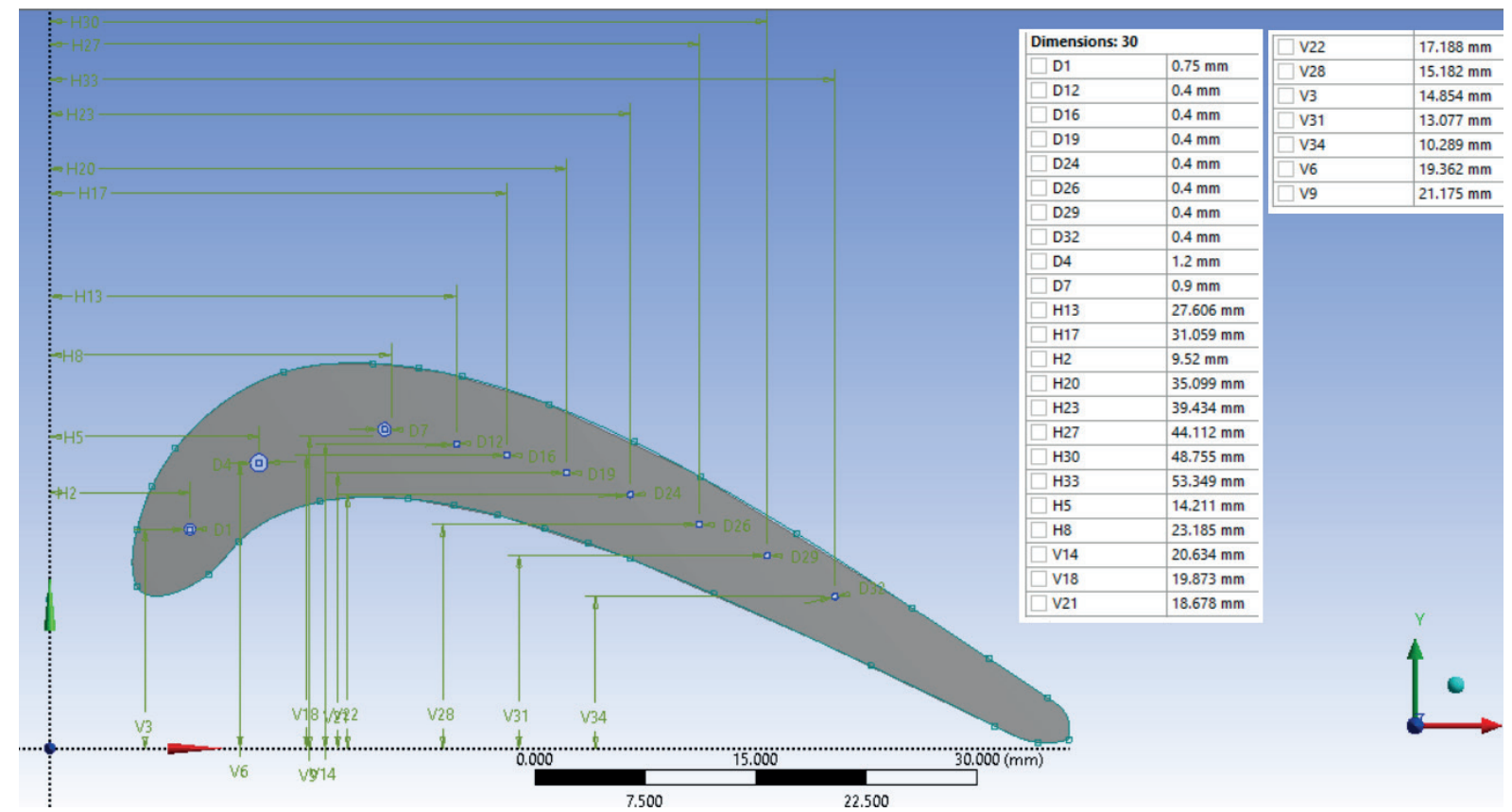

Figure 1 The geometry model of the turbine blade used in simulation including all dimensions

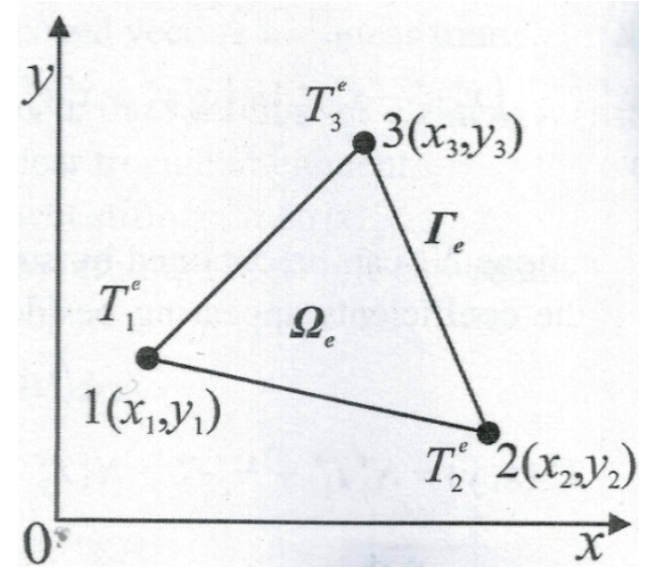

Figure 2 The linear triangular element with three nodes [4]

the internal cooling passage to reduce the pressure loss so that it does not demand increased coolant feed pressure. The high-fidelity numerical simulations predict improvement and, as a result, reducing the temperature of the turbine blade.

Baakeem, Orfi and Al-Ansary [8] achieved the optimum value of the cooled air temperature and presented the comparative study of widely used cooling methods by using mass and energy balance including mechanical vapor compression.

The research undertaken by Zhou et al. in [9] shows that film cooling effectiveness descends with the increasing blowing ratio. Numerical simulation proved that the blade middle-spane area has the thickest film cooling coverage.

He et al. [10] studied the cooling performances of three kinds of film holes (standard cylindrical film holes, transverse trenched and segmented trenched film holes). The research was undertaken with numerical method.

The film transfer cooling hole location and their dimension affect to film cooling system. It is proved by Zhou, Wang and $\mathrm{Li}$ [11] due to numerical investigation.

The major subject of Liu et al. paper [12] was modeling the film cooling flow of the turbine blade and compared results with developed method by adding end wall cooling part.

Wei et al. [13] performed the numerical simulation of effusion cooling mechanism by using different sizes of internal holes. During the modeling the inclination angle and the expansion angle were changing.

\section{Numerical analysis}

\subsection{Problem formulation}

The geometry of the turbine blade with cooling holes was created by using the Ansys software, the subject of this studies concentrates on the heat conduction by using the Finite Element Method application. The 


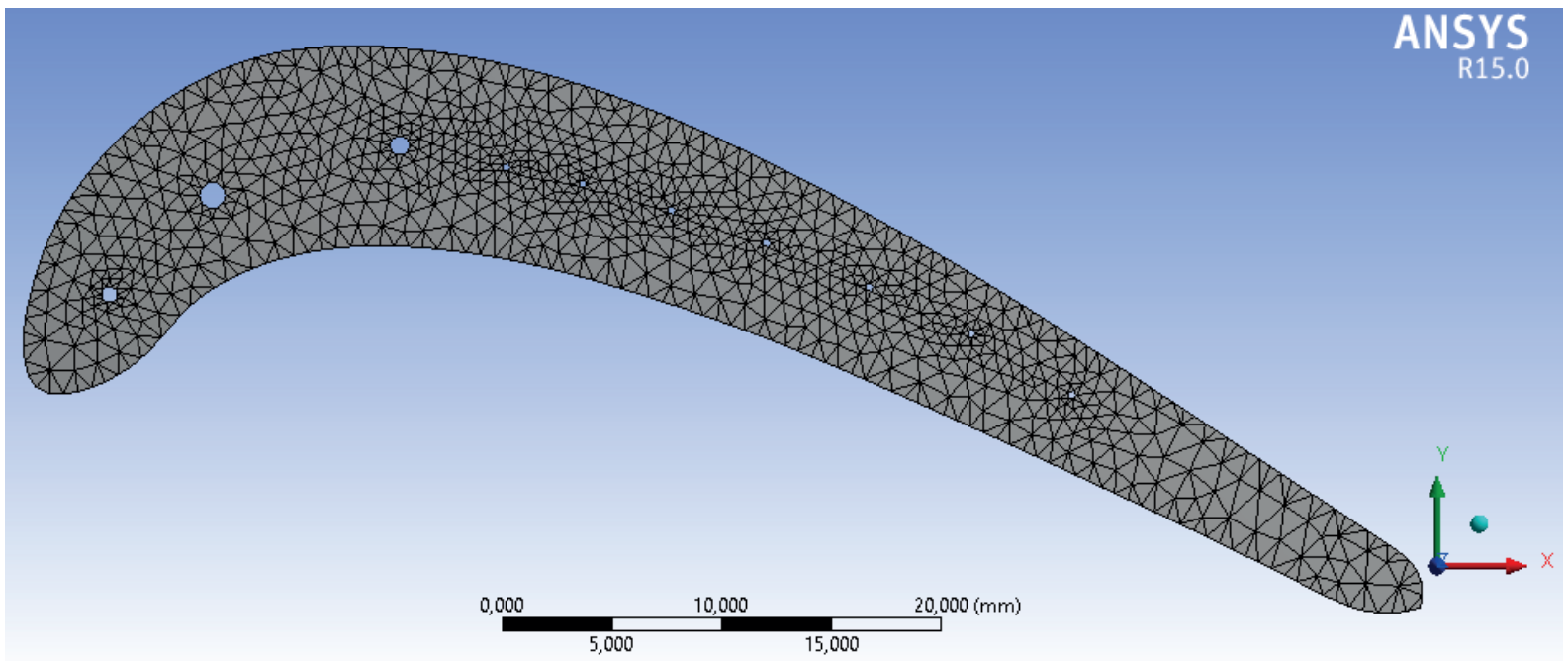

Figure 3 The geometry model after discretization process [15]

model considers the gas turbine blade with the cooling system. It had been managed by seven holes (Figure 1) through which the flowing air provides a decrease of temperature. All the dimensions and geometry are shown Figure 1.

The analysis considers the turbine blade cooled by the air passing through ten holes. The first three holes are marked as D1, D4 and D7, their dimensions are respectively $0.75 \mathrm{~mm}, 1.2 \mathrm{~mm}$ and $0.9 \mathrm{~mm}$. The remaining holes have the same dimension $-0.4 \mathrm{~mm}$.

The triangular method, used in the present analysis, consists of three nodes, therefore the temperature in the particular finite element was computed by using the temperatures in three nodes and shape function estimated in $\mathrm{x}, \mathrm{y}$ coordinates. The example triangular element is shown in Figure 2.

The temperature within the triangular element $\Omega^{\mathrm{e}}$ has been calculated by the function [14]:

$$
T^{e}(x, y)=a_{1}^{e}+a_{2}^{e} x+a_{3}^{e} y .
$$

The nodal coefficients $\left(a_{i}^{e}\right)$ are obtained by solving the three linear equations, each one is corresponding with individual node in triangular finite element. The temperature changes in the $\mathrm{x}$ and $\mathrm{y}$ directions, therefore, in each equation the individual nodal coordinates are used. After calculations, one obtains the following three equations [15]:

$$
\begin{aligned}
& a_{1}^{e}=\frac{1}{2 A^{e}}\left[\left(x_{2} y_{3}-x_{3} y_{2}\right) T_{1}^{e}+\left(x_{3} y_{1}-x_{1} y_{3}\right) T_{2}^{e} .\right. \\
& \left.\left(x_{1} y_{2}-x_{2} y_{1}\right) T_{3}^{e}\right], \\
& a_{2}^{e}=\frac{1}{2 A^{e}}\left[\left(y_{2}-y_{3}\right) T_{1}^{e}+\left(y_{3}-y_{1}\right) T_{2}^{e}\left(y_{1}-y_{2}\right) T_{3}^{e}\right], \\
& a_{3}^{e}=\frac{1}{2 A^{e}}\left[\left(x_{3}-x_{2}\right) T_{1}^{e}+\left(x_{1}-x_{3}\right) T_{2}^{e}\left(x_{2}-x_{1}\right) T_{3}^{e}\right] .
\end{aligned}
$$

$A^{e}$ is considered as an area of a triangular element.

As a result of substitution of coefficients into the
Equation (1), on obtains the shape functions for the three nodes of a finite element.

$$
\begin{aligned}
& N_{1}^{e}=\frac{1}{2 A^{e}}\left(a_{1}^{e}+b_{1}^{e} x+c_{1}^{e} y\right), \\
& N_{2}^{e}=\frac{1}{2 A^{e}}\left(a_{2}^{e}+b_{2}^{e} x+c_{2}^{e} y\right), \\
& N_{3}^{e}=\frac{1}{2 A^{e}}\left(a_{3}^{e}+b_{3}^{e} x+c_{3}^{e} y\right) .
\end{aligned}
$$

\subsection{Finite element model}

To obtain the discrete model, the Ansys - Workbench software was used. The geometry model after discretisation is shown in Figure 3. The whole structure has been divided into the finite elements by the mapped face meshing method. That feature automatically determines a suitable amount of divisions on the edges. However, the automatic method generates the high density of nodes around the circularly shaped cooling holes, therefore, for the better nodes arrangement on the whole surface the upper and lower edge were divided by applying the solid number of divisions (120 - for the upper and lower edge of the blade). In this analysis, the triangular method was applied, hence the number of nodes and elements are respectively 960 and 1633 .

\subsection{Boundary conditions}

Applied boundary conditions are shown in Figure 4. The following analysis is considered as a heat transfer in two dimensions. The convective surface boundary conditions are defined in locations in yellow and red. The outer blade's surface is divided into two segments "out 1" and "out 2". The inner surface is divided into ten sections "in 1" - "in 10" The material parameters and meticulous description of values and their units are shown in Table 1. It contains the thermal conductivity 


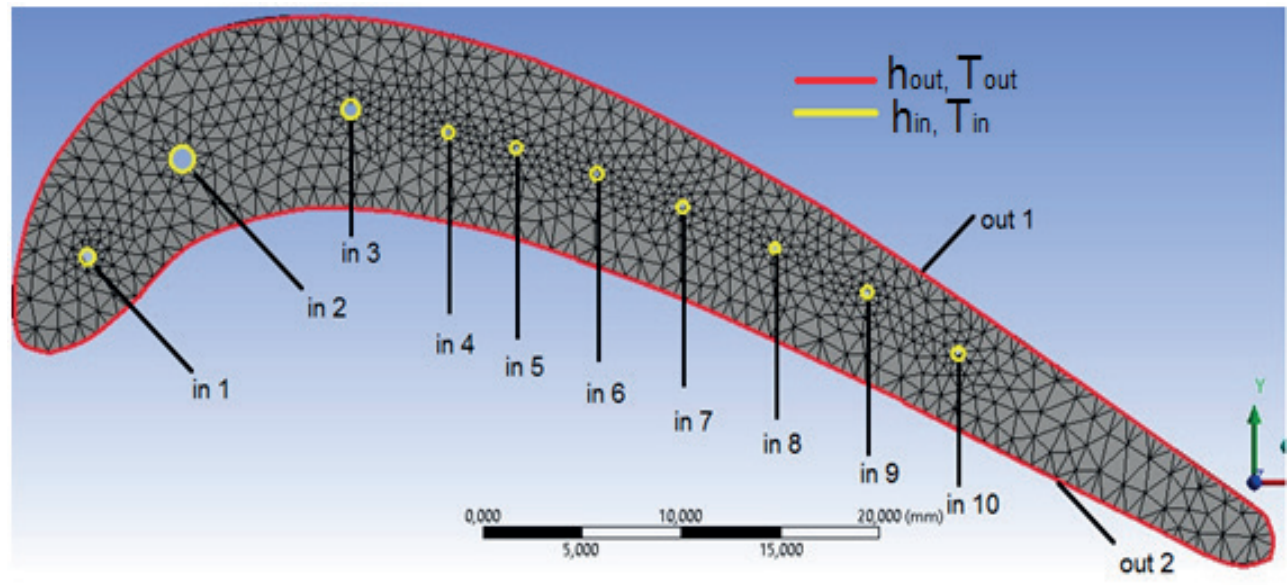

Figure 4 Finite element method of the turbine blade with applied boundary conditions

Table 1 Parameters of the transient heat transfer in the present case

\begin{tabular}{ccc}
\hline parameter & units & value \\
\hline thermal conductivity $(\mathrm{k})$ & $\frac{W}{m \times K}$ & 6.92 \\
density $(\rho)$ & $\frac{k g}{m^{3}}$ & 4540 \\
specific heat $(\mathrm{c})$ & $\frac{\mathrm{Jg} \times K}{2}$ & 460 \\
heat transfer coefficient in surfaces of turbine blade $\left(\mathrm{h}_{\text {in }}, \mathrm{h}_{\text {out }}\right)$ & $\frac{W}{m^{2} \times K}$ & $400-5000 / 1600$ \\
temperature on turbine blade surfaces $\left(\mathrm{t}_{\text {in }}, \mathrm{t}_{\text {out }}\right)$ & ${ }^{\circ} \mathrm{C}$ & $280 / 500$ \\
time step $(\delta \tau)$ & $s$ & from $1 \mathrm{x} 10^{-4}$ to $1 \mathrm{x} 10^{-3} 1 \mathrm{x} 10^{-3} \mathrm{~s}$ \\
initial temperature $\left(\mathrm{t}_{0}\right)$ & ${ }^{\circ} \mathrm{C}$ & 22 \\
\hline
\end{tabular}

of the blade $(k)$; specific heat of material used in analysis (c), convective heat transfer coefficients $h_{i n}, h_{\text {out }}$, volume of temperatures $T_{i n}, T_{\text {out }}$, time step $(\Delta \tau)$.

The high temperature in the compressor stages in aero engines is determined using titanium as a major component of material, which can withstand difficult conditions. The material used in simulation (Ti-6AL$2 \mathrm{Sn}-4 \mathrm{Zr}-2 \mathrm{Mo}$ ) is characterized by superior stability in the long term application at temperature over $540{ }^{\circ} \mathrm{C}$, therefore it is one of the most suitable material for compressor turbine blades, especially common in US in the jet engine applications [16-20].

\subsection{Crank Nicolson method}

The Crank-Nicolson method is used to solve calculations in numerical simulations related to the subject of the heat flow. The main second order partial differential equation (PDE) takes the following form:

$A \frac{\partial^{2} u}{\partial x^{2}}+B \frac{\partial^{2} u}{\partial x \partial y}+C \frac{\partial^{2} u}{\partial y^{2}}+D=0$,

where $A, B$ and, $C$ are independent variables of $x, y$, while $D$ can be a function of $x, y, u$. Equation (8) is called a parabolic partial differential equation, when the quadratic equation $\mathrm{B}^{2}-4 \mathrm{AC}=0$. Below is a diagram describing the principle of operation of the discussed method. The calculation attempt was made to conduct the heat through the one-dimensional element. The general form of the equation takes the form [20-22]:

$\alpha \frac{\partial^{2} T}{\partial x}=\frac{\partial T}{\partial t}$.

The method is based on the following differential scheme:

$$
\begin{aligned}
& \left.\frac{\partial^{2} T}{\partial x^{2}}\right|_{i, j} \approx \frac{1}{2}\left[\frac{T_{i+1}^{j}-2 T_{i}^{j}+T_{i-1}^{j}}{\left(\Delta x^{2}\right)}+\right. \\
& \left.+\frac{T_{i+1}^{j+1}-2 T_{i}^{j+1}+T_{i-1}^{j+1}}{\left(\Delta x^{2}\right)}\right] .
\end{aligned}
$$

The right part of the Equation (10) is the result of the arithmetic mean of the second degree derivative for position $x$ at time $j+1$ and $j$. Its main advantage is the more accurate result compared to the implicit method. This is due to the error of estimating the top for this method is $\mathrm{O}\left(\Delta \mathrm{t}^{2}+\Delta \mathrm{x}^{2}\right)$.

$$
\left.\frac{\partial T}{\partial}\right|_{i, j} \approx \frac{T_{i}^{j+1}-T_{i}^{j}}{\Delta t}
$$




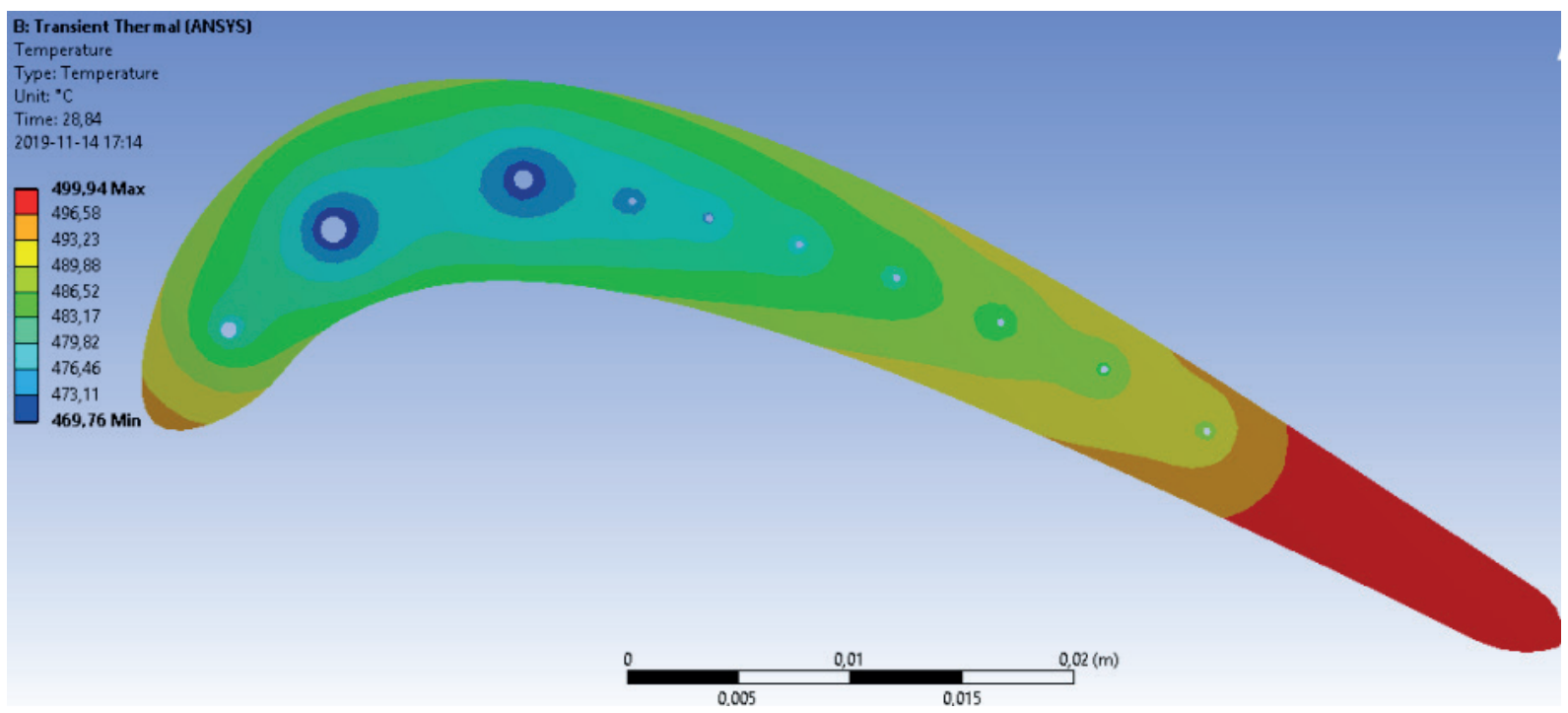

Figure 5 Temperature distribution in the turbine blade for the heat transfer coefficient $400 \mathrm{~W} /\left(\mathrm{m}^{2} \mathrm{~K}\right)$

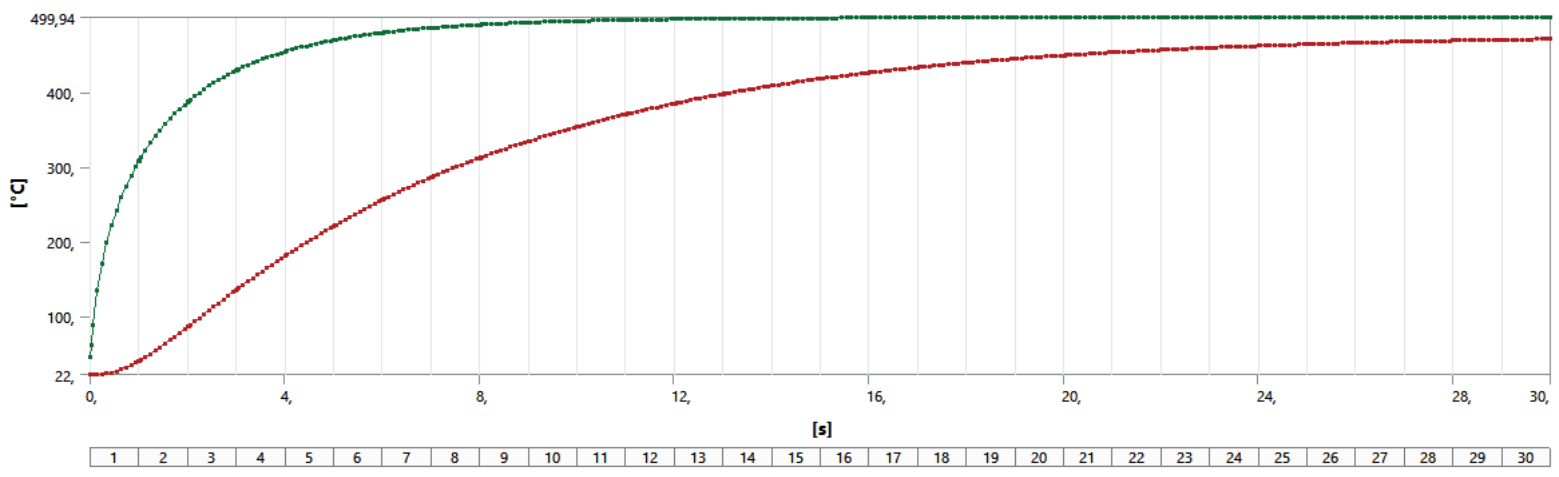

Figure 6 The result of the transient thermal analysis for the model parameters given in Table 1 in Ansys software.

$\alpha \frac{1}{2}\left[\frac{T_{i+1}^{j}-2 T_{i}^{j}+T_{i-1}^{j}}{(\Delta x)^{2}}+\right.$

$\left.+\frac{T_{i+1}^{j+1}-2 T_{i}^{j+1}+T_{i-1}^{j+1}}{(\Delta x)^{2}}\right]=\frac{T_{i}^{j+1}-T_{i}^{j}}{\Delta t}$.

The following equation is a linear equation, thanks to which one can calculate the temperature in all the nodes (except boundary conditions) at a given time.

$-\lambda T_{i-1}^{j+1}+2(1+\lambda) T_{i}^{j+1}-\lambda T_{i+1}^{j}=$

$\lambda T_{i-1}^{j}+2(1-\lambda) T_{i}^{j}+\lambda T_{i+1}^{j}$.

The Crank Nicolson method is an efficient technique of computing ordinary differential equations, which is based on the trapezoidal approximation to determine the temperature in nodes at time. Regarding the matrices and vectors, the formula is used:

$\{T\}^{n+1}=\{T\}^{n}+\left[\begin{array}{l}(1-\theta)\left\{\frac{d T}{d \tau}\right\}^{n}+ \\ +\theta\left\{\frac{d T}{d \tau}\right\}^{n+1}\end{array}\right] \Delta \tau$,

$\{T\}^{n}$ - temperature vector at $\mathrm{n}$ time level,

$\{T\}^{n+1}$ - temperature vector at $\mathrm{n}+1$ time level,

$\{d T\}^{n}$ - temperature derivative at $\mathrm{n}$ time level,

$\{d T\}^{n+1}$ - temperature derivative at $\mathrm{n}+1$ time level.
The equation which was used to determine nodal temperatures by using global matrices $[\mathbf{M}]$ and $[\mathbf{K}]$ and vector of nodes [f] is (14).

\section{Results}

After the meshing procedure and applying all the boundary conditions, the temperature of the turbine blade was calculated in twenty-four different heat transfer coefficient. In the next step, the same geometry and all the conditions were used in the simulation to obtain the results in the Ansys-Workbench and Matlab software. The results are presented in plots below.

\subsection{Transient thermal analysis}

The plots and visualizations of the transient thermal analysis of the turbine blade in the Ansys software for parameters given in Table 1 are shown below.

The transient thermal analysis (Figures 5 and 6) for the step controls: maximum time step: $0.001 \mathrm{~s}$; minimum time step: $0.0001 \mathrm{~s}$, the heat transfer coefficient was 400 


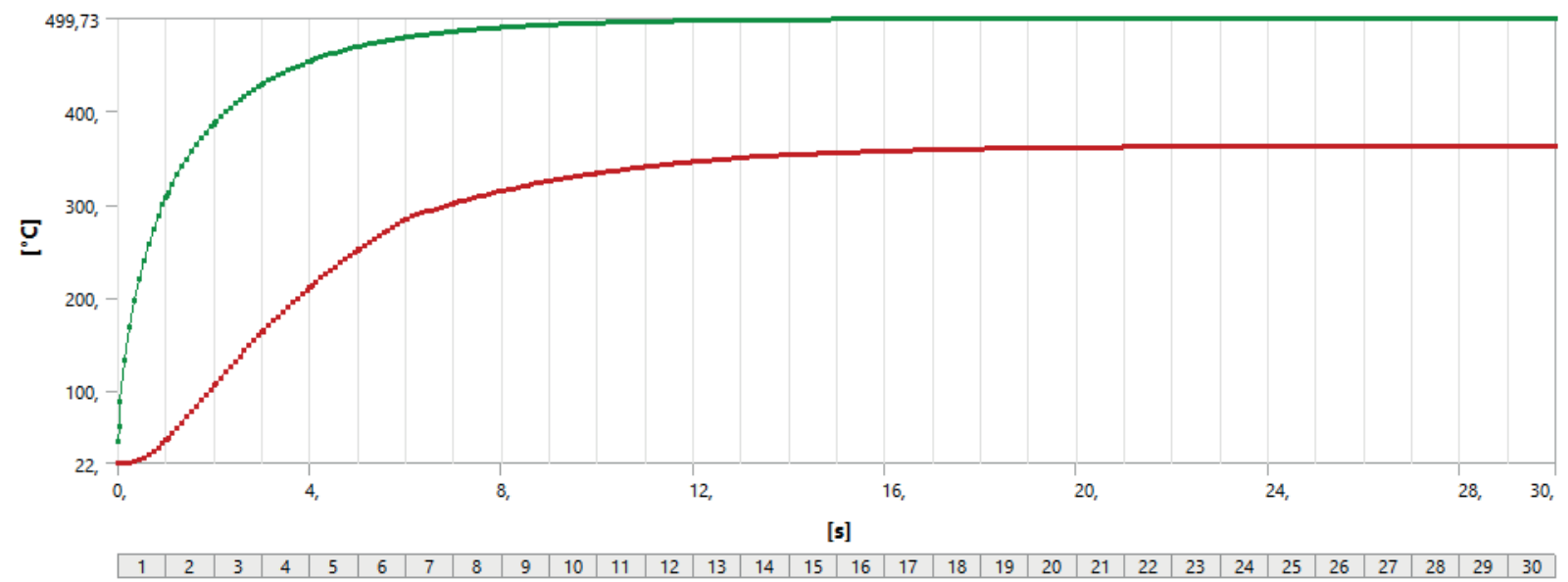

Figure 7 The result of the transient thermal analysis for the model parameters given in Table 1 in Ansys software.

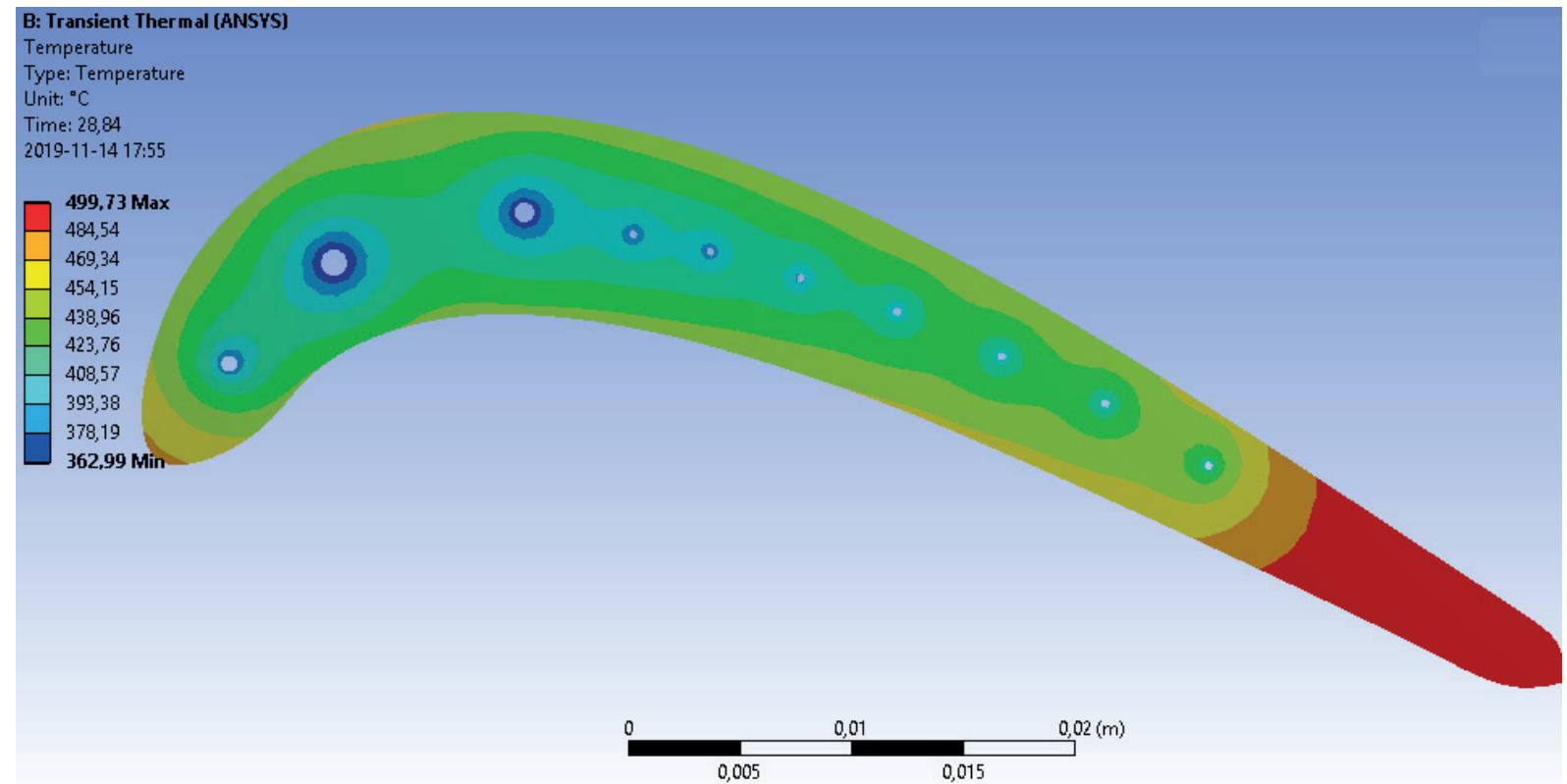

Figure 8The visualization of transient thermal analysis for heat transfer coeficient $5000 \mathrm{~W} /\left(\mathrm{m}^{2} \mathrm{~K}\right)$, model in AnsysWorkbench software

$\mathrm{W} /\left(\mathrm{m}^{2} \mathrm{~K}\right)$, the minimum and maximum temperature at the beginning of the calculation are respectively: 22.0 ${ }^{\circ} \mathrm{C}$ and $44.4{ }^{\circ} \mathrm{C}$, at the last second of computing the minimum and maximum temperatures are respectively: $470.7^{\circ} \mathrm{C}$ and $499.87^{\circ} \mathrm{C}$.

The analysis (Figures 7 and 8) for the step controls: maximum time step: $0.001 \mathrm{~s}$; minimum time step: 0.0001 $\mathrm{s}$, the heat transfer coefficient was $5000 \mathrm{~W} /\left(\mathrm{m}^{2} \mathrm{~K}\right)$, the minimum and maximum temperature at the beginning of the calculation are respectively: $22.0^{\circ} \mathrm{C}$ and 45.4 ${ }^{\circ} \mathrm{C}$, at the last second of computing the minimum and maximum temperature are respectively: $363.0{ }^{\circ} \mathrm{C}$ and $499.87^{\circ} \mathrm{C}$.

\subsection{Crank-Nicolson method}

The Crank-Nicolson soulutions for the model parameters given in Table 1, for the time step 0.001s, are shown in the plots below (Figures 9 and 10).
The heat transfer coefficients, applied in simulations, are $400 \mathrm{~W} /\left(\mathrm{m}^{2} \mathrm{~K}\right)$ and $5000 \mathrm{~W} /\left(\mathrm{m}^{2} \mathrm{~K}\right)$, respectively. Results of calculations are the minimum and maximum temperatures of the turbine blade. At the beginning of the analysis, the temperatures are $20.8{ }^{\circ} \mathrm{C}$ and 26.2 ${ }^{\circ} \mathrm{C}$, in both cases. At the last second of computing the minimum temperatures are $470.5{ }^{\circ} \mathrm{C}$ for $400 \mathrm{~W} /$ $\left(\mathrm{m}^{2} \mathrm{~K}\right)$ and $362.8{ }^{\circ} \mathrm{C}$ for $5000 \mathrm{~W} /\left(\mathrm{m}^{2} \mathrm{~K}\right)$. The maximum temperature for both plots is $499.9{ }^{\circ} \mathrm{C}$.

\subsection{Implicit method}

The implicit solutions for the model parameters given in Table 1 , for the time step $0.001 \mathrm{~s}$, are shown in the plots below (Figures 11 and 12). The heat transfer coefficients, applied in simulations, are $400 \mathrm{~W} /\left(\mathrm{m}^{2} \mathrm{~K}\right)$ and $5000 \mathrm{~W} /\left(\mathrm{m}^{2} \mathrm{~K}\right)$, respectively. At the beginning of analysis the temperatures are $21.8{ }^{\circ} \mathrm{C}$ and $26.2{ }^{\circ} \mathrm{C}$ in both cases. At the last second of computing the minimum 


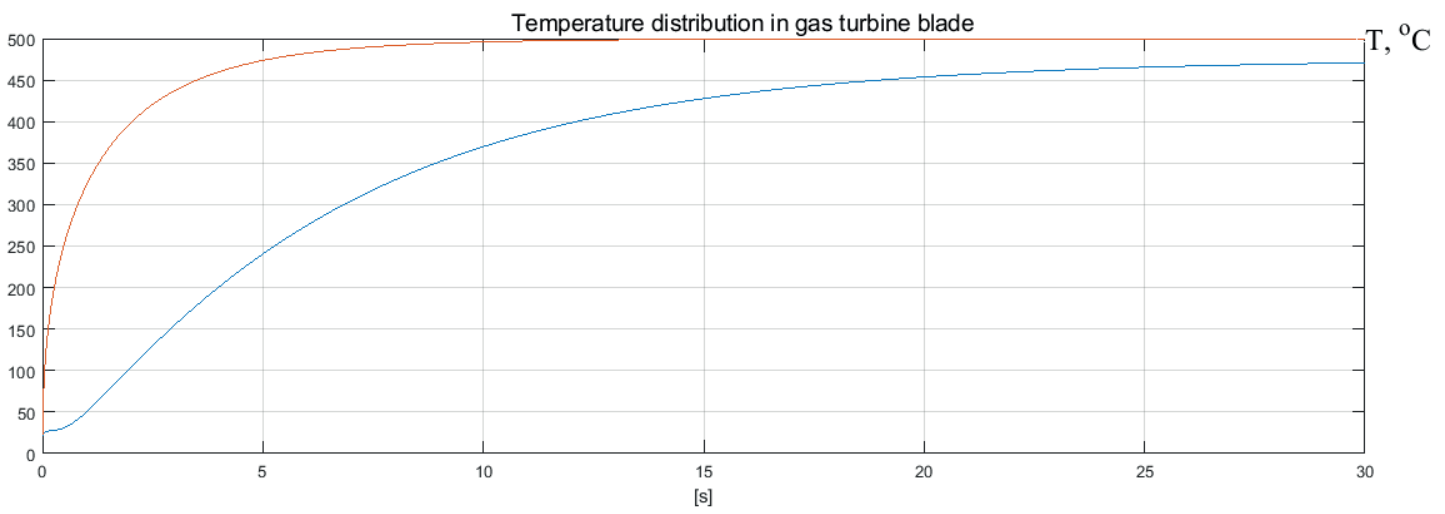

Figure 9 The Crank-Nicolson solution for the model parameters given in Table 1, the heat transfer coefficient was $400 \mathrm{~W} /\left(\mathrm{m}^{2} \mathrm{~K}\right)$

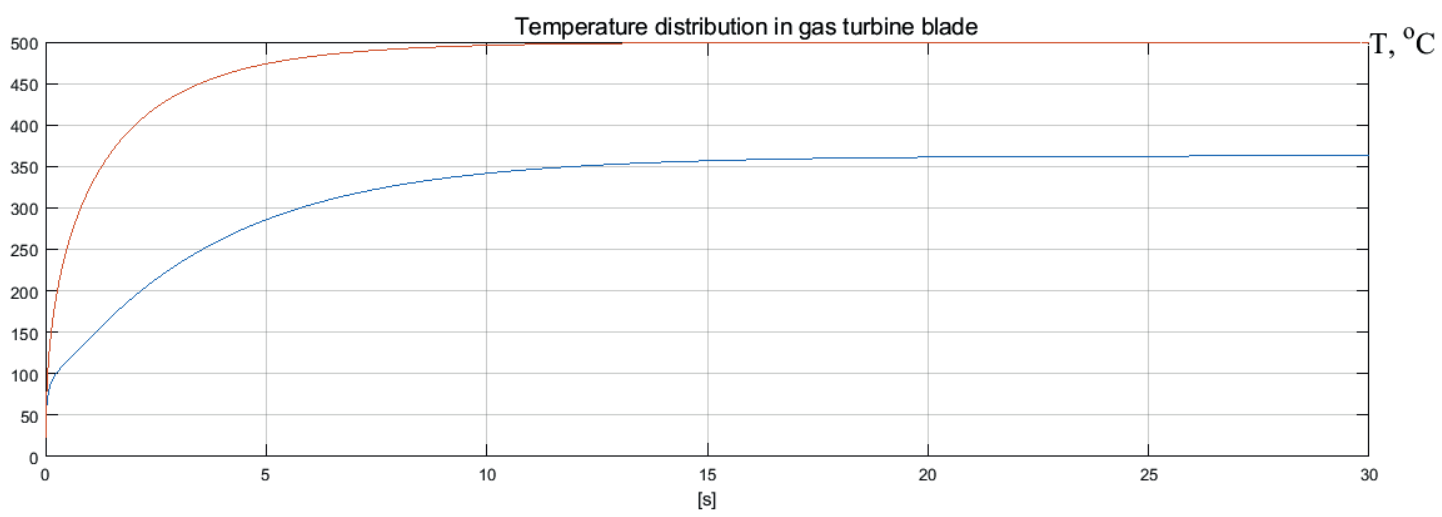

Figure 10 The Crank-Nicolson solution for the model parameters given in Table 1, the heat transfer coefficient was $5000 \mathrm{~W} /\left(\mathrm{m}^{2} \mathrm{~K}\right)$

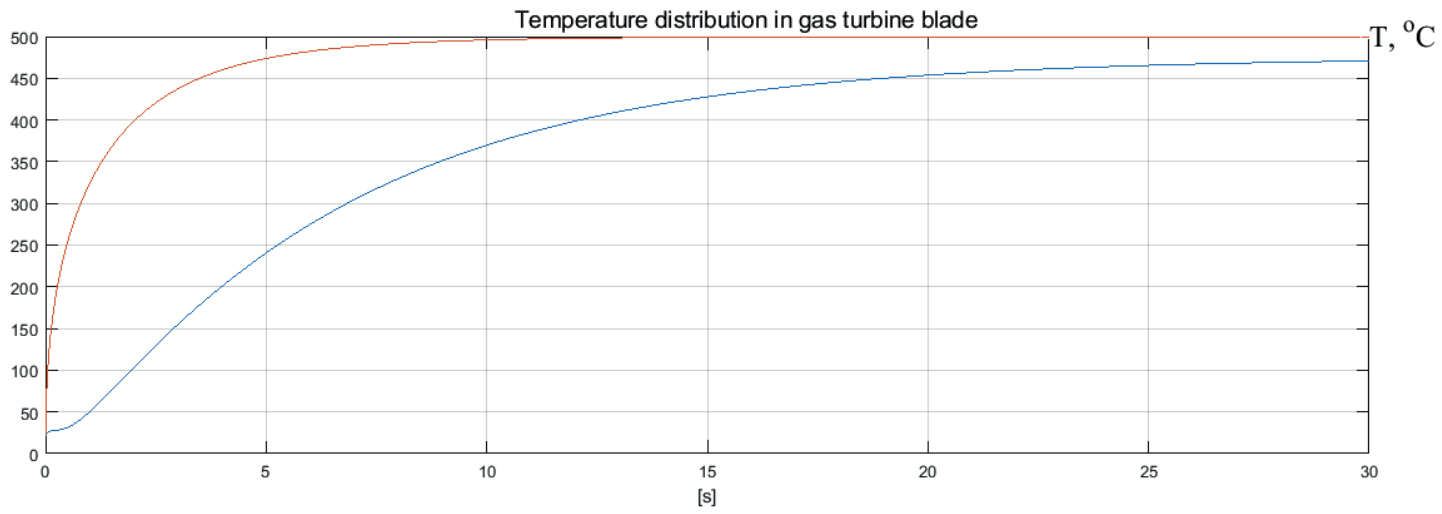

Figure 11 The implicit calculation for the model parameters given in Table 1, the heat transfer coefficient was $400 \mathrm{~W} /\left(\mathrm{m}^{2} \mathrm{~K}\right)$

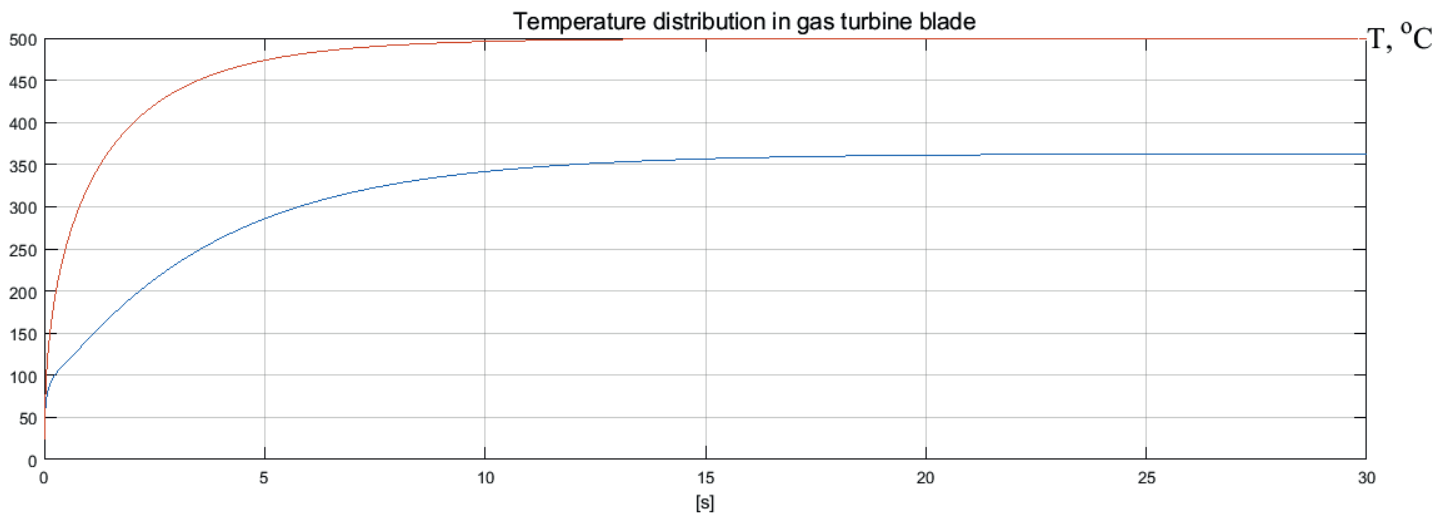

Figure 12 The implicit calculation for the model parameters given in Table 1, the heat transfer coefficient was $5000 \mathrm{~W} /\left(\mathrm{m}^{2} \mathrm{~K}\right)$ 


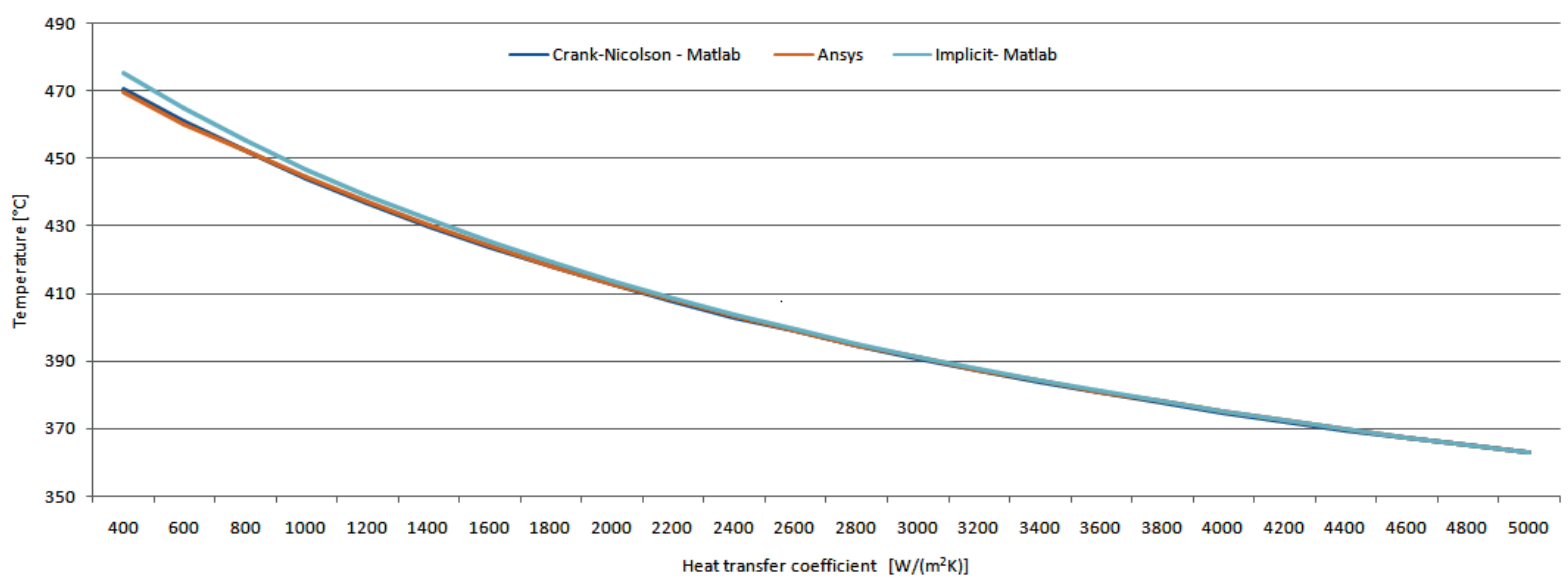

Figure 13 The influence of the heat transfer coefficient on the final temperature based on the three calculation methods

temperatures are $475.8^{\circ} \mathrm{C}$ for $400 \mathrm{~W} /\left(\mathrm{m}^{2} \mathrm{~K}\right)$ and $362.9{ }^{\circ} \mathrm{C}$ for $5000 \mathrm{~W} /\left(\mathrm{m}^{2} \mathrm{~K}\right)$. The maximum temperature is $499.9{ }^{\circ} \mathrm{C}$ in both cases.

\section{Conclusions}

The mathematical model of the turbine blade heat exchange was prepared by the three different methods. The optimal time step of calculation for Explicit and Implicit, Crank-Nicolson method were selected which gives convergent results, what is shown in the plot below (Figure 13).

- As the heat transfer coefficient increases the efficiency of the cooling holes rises as well, therefore the temperature of the turbine blade wall has been reduced.

- The smaller value of the heat transfer coefficient, the poorer cooling efficiency has occurred. The maximum temperature calculated in the hottest part of the blade was $499.9^{\circ} \mathrm{C}$, as a consequence the differences between the lowest and the highest point of temperature was only $30{ }^{\circ} \mathrm{C}$.

- In the highest value of heat transfer coefficient, efficiency of the cooling holes is the most significant. The difference between the lowest and the highest point of temperature was $136{ }^{\circ} \mathrm{C}$

The presented solution provides an effective way to reduce the temperature of the front part turbine blade (cooling area).

\section{References}

[1] BOYCE, M. P. An overview of a gas turbines. Gas turbine engineering handbook. 2. ed. Boston: Gulf Professional Publishing, 2011. ISBN 9780123838421, eISBN 9780123838438.

[2] XUE, S., NG, W.F. Turbine blade tip external cooling technologies. Aerospace [online]. 2018, 5(3), 90. eISSN 2226-4310. Available from: https://doi.org/10.3390/aerospace5030090

[3] GUPTA, A. Vocational training report new turbine shop - block 15. India: Bharat Heavy Electrical Limited, Mechanical Engineering Manav Rachna University, 2017.

[4] HAN, F., GUO, H., DING, X.-F., ZHANG, D.-W., LI, H.-W. Experimental investigation on the effects of hole pitch and blowing ratio on the leading edge region film cooling of a rotating twist turbine blade. International Journal of Heat and Mass Transfer [online]. 2020, 150, 119380. ISSN 0017-9310. Available from: https://doi.org/10.1016/j. ijheatmasstransfer.2020.119380

[5] MISHRA, S., SANJAY. Energy and exergy analysis of air-film cooled gas turbine cycle: Effect of radiative heat transfer on blade coolant requirement. Applied Thermal Engineering [online]. 2018, 129, p. 1403-1413. ISSN 1359-4311. Available from: https://doi.org/10.1016/j.applthermaleng.2017.10.128

[6] KAMAL, S. N. O., SALIM, D. A., FOUZI, M. S. M., KHAI, D. T. H., YUSOF, M. K. Y. Feasibility study of turbine inlet air cooling using mechanical chillers in Malaysia climate. Energy Procedia [online]. 2017, 138, p. 558-563. ISSN 1876-6102. Available from: https://doi.org/10.1016/j.egypro.2017.10.159

[7] KIM, CH., SON, CH. Rapid design approach for U-bend of a turbine serpentine cooling passage. Aerospace Science and Technology [online]. 2019, 92, p. 417-428. ISSN 1270-9638. Available from: https://doi.org/10.1016/j. ast.2019.05.019

[8] BAAKEEM, S. S., ORFI, J., AL-ANSARY, H. Performance improvement of gas turbine power plants by utilizing turbine inlet air-cooling (TIAC) technologies in Riyadh, Saudi Arabia. Applied Thermal Engineering [online]. 2018, 138, p. 417-432. ISSN 1359-4311. Available from: https://doi.org/10.1016/j.applthermaleng.2018.04.018 
[9] ZHOU, Z., LI, H., WANG, H., XIE, G., YOU, R. Film cooling of cylindrical holes on turbine blade suction side near leading edge. International Journal of Heat and Mass Transfer [online]. 2019, 141, p. 669-679. ISSN 0017-9310. Available from: https://doi.org/10.1016/j.ijheatmasstransfer.2019.07.028

[10] HE, W., DENG, Q., ZHOU, W., GAO, T., FENG, Z. Film cooling and aerodynamic performances of a turbine nozzle guide vane with trenched cooling holes, Applied Thermal Engineering [online]. 2019, 150, p. 150-163. ISSN 1359-4311. Available from: https://doi.org/10.1016/j.applthermaleng.2019.01.002

[11] ZHOU, J., WANG, X., LI, J. Influences of effusion hole diameter on impingement/effusion cooling performance at turbine blade leading edge. International Journal of Heat and Mass Transfer [online]. 2019, 134, p. 1101-1118. ISSN 0017-9310. Available from: https://doi.org/10.1016/j.ijheatmasstransfer.2019.02.054

[12] LIU, J. H., LIU, Y. B., LIU, L. Film cooling modeling of a turbine vane with multiple configurations of holes. Case Studies in Thermal Engineering [online]. 2018, 11, p. 71-80. ISSN 2214-157X. Available from: https://doi. org/10.1016/j.csite.2018.01.001

[13] WEI, H., AI, J. L., ZU, Y. Q., DING, L. Heat transfer characteristics of fan-shaped hole effusion cooling for a constant hole exit width -numerical simulation and experimental validation. Applied Thermal Engineering [online]. 2019, 160, 113978. ISSN 1359-4311. Available from: https://doi.org/10.1016/j.applthermaleng.2019.113978

[14] TALER J, OCLON, P. Finite element method in steady-state and transient heat conduction. In: Encyclopedia of thermal stresses. HETNARSKI, R. B. (ed.). Dordrecht, Holland: Springer, 2014. ISBN 978-94-007-2738-0, eISBN 978-94-007-2739-7.

[15] OCLON, P. Heat conduction equation for plane 2D problems. Numerical modeling of heat transfer and fluid flow processes with energy engineering applications. Cracow: Cracow University of Technology, 2015.

[16] BENINI, E. Materials for gas turbines - an overview. In: Advances in gas turbine technology[online]. BENINI, E. (ed.). Italy: IntechOpen, 2011. ISBN 978-953-307-611-9, eISBN 978-953-51-4411-3. Available from: https://doi.org/10.5772/664

[17] GURRAPPA, I., YASHWANTH, V. S., GOGIA, A. K. The selection of materials for marine gas turbine engines. In: Efficiency, performance and robustness of gas turbines [online]. VOLKOV, K. (ed.). United Kingdom: IntechOpen, 2012. ISBN 978-953-51-0464-3, eISBN 978-953-51-6191-2. Available from: https://doi.org/10.5772/2595

[18] GADDAM, R., SAFER, B., PEDERSON, R., ANTTI, M.-L. Study of alpha -case depth in Ti-6Al-2Sn-4Zr-2Zr2Mo and Ti-6Al-4V. IOP Conference Series: Materials Science and Engineering [online]. 2013, 48, 012002. ISSN 1757-8981, eISSN 1757-899X.Available from: https://doi.org/10.1088/1757-899X/48/1/012002

[19] Timet_DataSheets_6242 [online] [accessed 2019-09-07] Available from:http://www.timet.com/assets/local/ documents/datasheets/alphaalloys/6242.pdf

[20] BEGUM, F., REDDY, V. V. R., RAMANJANEYULU, S. Design and thermal analysis of cooling of gas turbine blade through radial holes. Materials Today: Proceedings [online]. 2017, 4(8), p. 7714-7722. ISSN 2214-7853. Available from: https://doi.org/10.1016/j.matpr.2017.07.106

[21] Holistic numerical methods [online] [accessed 2020-05-17]. Available from: http://nm.mathforcollege.com/topics/ pde_parabolic.html

[22] WENG, Z., FENG, X., HUANG, P. A new mixed finite element method based on the Crank-Nicolson scheme for the parabolic problems. Applied Mathematical Modelling [online]. 2012, 36(10), p. 5068-5079. ISSN 0307-904X. Available from: https://doi.org/10.1016/j.apm.2011.12.044 
Annex - Nomenclature

\begin{tabular}{|c|c|}
\hline nomenclature & meaning \\
\hline \multicolumn{2}{|c|}{ Roman symbols } \\
\hline A & area, $\mathrm{m}^{2}$ \\
\hline $\mathrm{C}$ & specific heat capacity, $\mathrm{J} /(\mathrm{kg} \cdot \mathrm{K})$ \\
\hline $\mathrm{h}$ & heat transfer coefficient, $\mathrm{W} /\left(\mathrm{m}^{2} \mathrm{~K}\right)$ \\
\hline $\mathrm{h}$ & enhanced heat transfer coefficient based on outer tube surface $A_{0}, W /\left(m^{2} K\right)$ \\
\hline $\mathrm{k}$ & thermal conductivity, $\mathrm{W} /(\mathrm{mK})$ \\
\hline $\mathrm{N}_{\mathrm{i}}$ & finite element shape function refferd to i-th node \\
\hline $\mathrm{T}$ & temperature, ${ }^{\circ} \mathrm{C}$ \\
\hline $\mathrm{T}_{\mathrm{in}}$ & initial temperature, ${ }^{\circ} \mathrm{C}$ \\
\hline $\mathrm{x}, \mathrm{y}$ & Cartesian coordinates, $\mathrm{m}$ \\
\hline$-\mathrm{T}$ & temperature as a function of place, $\mathrm{x}$ and time $\mathrm{t}$ \\
\hline$-\alpha$ & thermal diffusivity obtained by equation $\alpha=\frac{k}{\rho C}$ \\
\hline$-\mathrm{k}$ & thermal conductivity \\
\hline$-\mathrm{C}$ & specific heat \\
\hline \multicolumn{2}{|c|}{ Matrices and vectors } \\
\hline$\{\mathbf{f}\}$ & vector of nodal loads \\
\hline$\{\mathbf{K}\}$ & stiffness matrix \\
\hline$\{\mathbf{T}\}$ & vector of nodal temperatures \\
\hline \multicolumn{2}{|l|}{ Greek symbols } \\
\hline$\alpha$ & line search parameter; temperature coefficient \\
\hline$\tau$ & time, $\mathrm{s}$ \\
\hline$\rho$ & density, kg.m³ \\
\hline
\end{tabular}

